\title{
ANALISIS FAKTOR-FAKTOR YANG MEMPENGARUHI PURCHASE INTENTION KONSUMEN PADA TRAVELOKA.COM
}

\author{
Wisnu Purnama Sidhi Setio \\ Program Studi Magister Manajemen Universitas Tarumanagara \\ walterwisnu@gmail.com \\ Suwinto Johan \\ Program Studi Magister Manajemen Universitas Tarumanagara
}

Masuk : 06-06-2020, revisi : 07-07-2020 diterima untuk diterbitkan : 07-07-2020

\begin{abstract}
The purpose of this research is to analyze correlation between information quality, perceived web security to perceived trust, correlation between convenience, web interface quality to perceived ease of use, and correlation between brand image, perceived trust and perceived ease of use to purchase intention consumer at Traveloka.com. This study is a descriptive research, the sampling technique used in this study is nonprobability sampling by convenience sampling using a quantitative approach by distributing questionnaire to 100 respondents Traveloka's users in Jakarta, the object of this research is Traveloka.com and data processing techniques using structural equation modeling supported by the SmartPLS program.3.2.8. The results of this study indicate that information quality \& perceived web security had a positive effect on the perceived trust. Convenience \& web interface quality does not affect the perceived ease of use. Brand image, perceived trust \& perceived ease of use had a positive effect on purchase intention.
\end{abstract}

Keywords: Brand Image, Perceived Trust, Perceived Ease of Use, Purchase Intention

Abstrak: Tujuan dari penelitan ini adalah untuk menganalisis apakah ada pengaruh dari information quality, perceived web security terhadap perceived trust, pengaruh convenience, web interface quality terhadap perceived ease of use, dan pengaruh brand image, perceived trust dan perceived ease of use terhadap purchase intention konsumen di Traveloka.com. Penelitian ini jenisnya adalah penelitian deskriptif, menggunakan teknik pengambilan sampel yang digunakan pada penelitian ini adalah nonprobability sampling, dengan cara convenience sampling menggunakan pendekatan kuantitatif dengan menyebarkan kuesioner sebanyak 100 responden pengguna Traveloka di Jakarta, sementara objek penelitiannya adalah Traveloka.com dan teknik pengolahan data menggunakan pemodelan persamaan struktural yang dibantu oleh program SmartPLS.3.2.8. Hasil penelitian ini menunjukkan bahwa information quality \& perceived web security berpengaruh positif terhadap perceived trust. Convenience \& web interface quality tidak berpengaruh terhadap perceived ease of use. Brand image, perceived trust \& perceived ease of use berpengaruh positif terhadap purchase intention.

Kata kunci: Citra Merek, Niat Beli, Persepsi Kepercayaan, Persepsi Kemudahaan

\section{PENDAHULUAN}

Traveling menjadi sangat popular hampir di setiap negara di dunia, tidak terkecuali di Indonesia. Secara akademik topik online buying juga sangat menarik untuk dibahas, karena memberikan perubahan cara konsumen untuk membeli barang yang mereka inginkan dari pembelian secara offline di pusat kota menjadi transaksi secara digital, dengan berbagai alasan, mulai dari menghemat waktu, dapat mengakses berbagai komoditas dengan mudah, dan mencari barang dengan harga termurah. Hal ini juga berpengaruh terhadap perubahan perilaku konsumen untuk melakukan pembelian tiket atau melakukan booking hotel, tiket masuk 
wahana atau melakukan pembelian jasa untuk perjalanan traveling mereka yang pada saat ini sebagian besar konsumen melakukan aktivitas tersebut secara online melalui gawai mereka.

Semakin meleburnya ketatnya industri agent travel online atau online ticketing membuat, sebagai contoh Tokopedia, bukalapak, JD.id dan Blibli.com yang dulu dikenal sebagai ecommerce atau marketplace sudah mulai masuk ke ranah bisnis online ticketing juga dengan persaingan industri agen travel online yang sangat ketat, Traveloka terus meningkatkan brand image dan trust dengan jaminan harga termurah yang dijual.

Beberapa keunggulan kualitas pelayanan yang dimiliki oleh Traveloka diantaranya yaitu perbandingan harga maskapai/hotel yang ditampilkan secara lengkap dan jelas, kemudahan dalam melakukan reschedule, harga yang sudah termasuk pajak dan biaya lainnya serta fasilitas refund. Secara agresif Traveloka terus mengembangkan usahanya di Indonesia. Untuk itu penting untuk Traveloka mengetahui faktor apa saja yang mempengaruhi konsumen di Indonesia untuk mau berbelanja di Traveloka.

Berdasarkan uraian yang tersebut, penulis tertarik melakukan penelitian dengan tujuan untuk mnganalasis mengenai faktor-faktor yang mempengaruhi purchase intention konsumen terhadap online travel agent Traveloka. Dengan variabel yang digunakan adalah brand image, perceived web security, convenience, web interface quality, information quality, perceived trust, dan perceived ease of use.

\section{TELAAH KEPUSTAKAAN Information Quality}

Kotler dan Armstrong (2014) menyampaikan bahwa sebagai media pemberi informasi, tampilan website yang menarik disajikan sebagai salah satu tolak ukur bagi pengunjung dan konsumen potensial untuk menilai apakah websitenya tersebut mempunyai kinerja yang bagus atau tidak.

\section{Perceived Web Security}

Flavia'n dan Guinali'u (2006) mengartikan persepsi keamanan sebagai kemungkinan kepercayaan subjektif yang dimiliki konsumen bahwa informasi pribadi mereka (dalam aspek perdata dan moneter) tidak akan dilihat, disimpan, dan dimanipulasi oleh pihak lain selama dalam perjalan dan penyimpanan, sehingga secara konsisten menimbulkan harapan kepercayaan diri mereka.

\section{Perceived Trust}

Menurut Chen \& Chung (2010), kepercayaan juga mengacu pada keyakinan positif tentang keandalan dan dapat dipertanggung-jawabkan dari seseorang atau suatu objek.

\section{Convenience}

Menurut Kotler (2012) mendefinisikan produk yang pelanggan biasa beli, langsung saat itu juga, dengan usaha yang sekecil-kecilnya. Kenyamanan merupakan keadaan dimana seorang menggunakan suatu teknologi dalam melakukan aktivitasnya dan dianggap nyaman untuk dirinya sendiri.

\section{Web Interface Quality}

Menurut Shneiderman dan Plaisant (2010), terdapat aturan emas (Eight Golden Rules) yang digunakan sebagai pedoman dalam merancang suatu antarmuka pengguna (web user interface) yang baik, diantaranya: mempertahankan konsistensi, mengenali kebutuhan user yang beragam, memberikan umpan balik yang informatif, merancang dialog penutupan, memberikan penanganan kesalahan yang sederhana, memberikan kemudahan untuk kembali ke tindakan sebelumnya, mendukung pusat kendali internal, mengurangi beban ingatan jangka pendek.

\section{Perceived Ease of Use}

Menurut Davis et al., (1989) adalah tingkat sejauh mana seseorang percaya bahwa menggunakan sistem akan bebas dari usaha, atau dapat juga diartikan sebagai keyakinan sejauh mana sebuah sistem akan mengurangi usaha mereka dalam bertindak. 


\section{Brand Image}

Kotler dan Armstrong (2014:233) mengemukakan pengertian citra merek "The set of belief held about a particular brand is known as brand image". Yang artinya adalah sekumpulan keyakinan terhadap suatu merek disebut citra merek.

\section{Purchase Intention}

Menurut Kotler (2012) definisi Purchase Intention adalah "consumer behaviour occur when consumer stimulated by external factors and cometo purchase decision based their personal chacacteristics and decision making process". Yang artinya adalah perilaku konsumen yang dipengaruhi dari faktor eksternal dan berdasarkan karakteristik personal dan proses pengambilan keputusan.

\section{Kerangka Penelitian}

Variabel yang digunakan di penelitian ini ada lima variabel bebas yaitu information quality sebagai variabel X1, perceived web security sebagai variabel X2, convenience sebagai variabel X3, website interface quality sebagai variabel $\mathrm{X} 4$, brand image sebagai variabel X5, perceived trust sebagai variabel X6, dan perceived ease of use sebagai variabel X7.

\section{Gambar 1}

Kerangka Penelitian

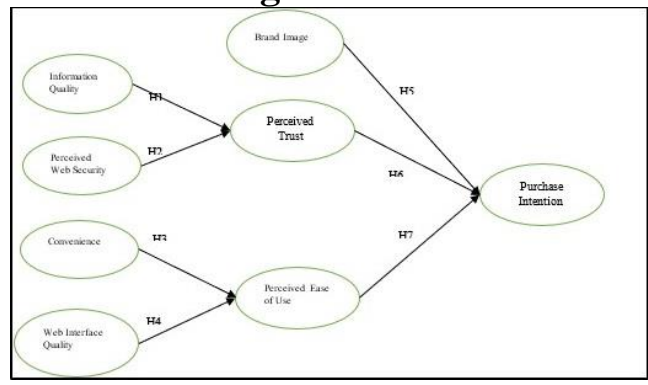

\section{Hipotesis}

H1 : Hubungan Information Quality berpengaruh secara signifikan dengan Perceived trust

H2 : Hubungan Perceived Web Security berpengaruh secara signifikan dengan Perceived Trust

H3 : Hubungan Convenience berpengaruh secara signifikan dengan Perceived Ease of Use

$\mathrm{H} 4$ : Hubungan Web Interface Quality berpengaruh secara signifikan dengan Perceived Ease of Use

H5 : Hubungan Brand Image berpengaruh secara signifikan dengan Purchase Intention

H6 : Hubungan Perceived trust berpengaruh secara signifikan dengan Purchase Intention

H7 : Hubungan Perceived Ease of Use berpengaruh secara signifikan dengan Purchase Intention

\section{METODOLOGI PENELITIAN}

Jenis penelitian yang dilakukan adalah penelitian deskriptif kuantitatif. Periode penelitian ini adalah April 2020 - Juni 2020. Metode pengumpulan data pada penelitian berbentuk pengambilan sampel dari suatu populasi dan menggunakan kuesioner sebagai alat pengumpulan data. Teknik pemilihan sampel yang digunakan dalam penelitian ini adalah convenience sampling dimana dalam pengambilan sampel didasarkan pada ketersediaan elemen dan kemudahan untuk mendapatkannya. Sampel dalam penelitian ini sebesar 100 responden, men hasil dari perhitungan menggunakan formula slovin menurut Tejada \& Punzalan (2012) dengan rumus:

Keterangan:

$$
n=\frac{N}{1+N e^{2}}
$$

$n=$ Jumlah Sampel

$N=$ Jumlah Seluruh Populasi

$e=$ Toleransi Error 
Dalam penelitian ini alpha ditetapkan sebesar 10\%, populasi penguna Traveloka pada 2018 sebesar \pm 40 juta pengguna menurut public relation manager Traveloka, Busyra Oryza, dalam artikel akurat.co (Mahmuddhin, R. 2018), dengan populasi sebesar \pm 40 juta maka perhitungan sample:

$$
99,99=\frac{40.000 .000}{1+40.000 .000 \times 0,1^{2}}
$$

Maka minimal sample sebesar 99,99 atau dibulatkan menjadi 100 responden, pengumpulan data pada penelitian ini dilakukan dengan pembagian kuesioner secara online dengan menggunakan google-form kepada responden yang pernah menggunakan Traveloka. Metode analisis data dalam penelitian ini menggunakan structure equation modeling (SEM) dengan bantuan program SmartPLS 3.2.8.

Berdasarkan data yang telah dikumpulkan dari 100 responden, diketahui bahwa mayoritas responden berjenis kelamin perempuan sebesar 53 orang atau sebesar 53\%, sebesar 78 orang atau sebesar $78 \%$ responden berusia 20-30 tahun. Responden pada penelitian ini, sebesar 61 orang atau $61 \%$ memiliki pekerjaan sebagai karyawan swasta dan sebanyak 51 orang atau 51\% memiliki pengeluaran < Rp. 5.000.000,00, sebesar 37 orang atau 37\% responden memiliki income < Rp. 8.000.000,00, dan mayoritas responden sebesar 65 orang atau $65 \%$ responden memiliki Pendidikan $\mathrm{S} 1$.

\section{HASIL UJI STATISTIK DAN PEMBAHASAN}

Hasil pengujian koefisien determinasi $\mathrm{R}^{2}$ dari penelitian ini menunjukan nilai presentase variabel purchase decision sebesar $47,3 \%$ yang berarti variabel purchase intention dapat dijelaskan oleh variabel brand image, perceived trust serta perceived ease of use dan sisanya sebesar 52,7\% dari variabel purchase intention dapat dijelaskan oleh variabel lain diluar penelitian ini. Berdasarkan hasil tersebut, maka koefisien determinasi pada penelitian ini tergolong cukup.

Hasil analisis data secara singkat tertera pada Tabel 1. berikut ini:

Tabel 1

Hasil Pengujian Hipotesis

\begin{tabular}{clcc}
\hline & \multicolumn{1}{c}{ Hipotesis } & Coefficient & T-statistic \\
\hline H1 & Information Quality -> Perceived trust & 0,403 & $5,300^{*}$ \\
\hline H2 & Perceived Web Security -> Perceived trust & 0,501 & $6,883^{*}$ \\
\hline H3 & Convenience -> Perceived Ease of Use & 0,139 & $0,895^{*}$ \\
\hline H4 & Web Interface Quality -> Perceived Ease of Use & 0,234 & $1,582^{*}$ \\
\hline H5 & Brand Image -> Purchase Intention & 0,304 & $2,175^{*}$ \\
\hline H6 & Perceived trust -> Purchase Intention & 0,320 & $2,341^{*}$ \\
\hline H7 & Perceived Ease of Use -> Purchase Intention & 0,193 & $2,179^{*}$ \\
\hline
\end{tabular}

Sumber: Hasil Pengolahan Data dengan SmartPLS 3.2.8

Berdasarkan Tabel 1. di atas dapat ditarik kesimpulan bahwa variable information quality memberi kontribusi besar kepada perceived trust dengan memberikan kontribusi sebesar 0,403, sedangkan variable perceived web security memberikan kontribusi kepada perceived trust sebesar 0,501. Sementara variabel conveniene dan web interface quality diketahui tidak berpengaruh terhadap perceived ease of use karna uji T-statistic kurang dari 1,96 masing masing 0,895 dan 1,582. Sementara variabel perceived trust memberikan kontribusi terbesar terhadap prediksi purchase intention yang dibuktikan oleh nilai path coefficients yaitu sebesar 0,320 dan diketahui variabel brand image, perceived trust memberikan kontribusi terhadap prediksi purchase intention berturut-turut sebesar 0,304 dan 0,193. Sedangkan untuk hasil pengujian seluruh hipotesis, variabel brand image, perceived trust, perceived ease of use terbukti mampu memprediksi secara positif purchase intention. Hal ini dibuktikan dengan nilai T-statistics lebih besar dari cut off value sebesar 1,96 sehingga dapat disimpulkan bahwa H5, H6, dan H7, tidak ditolak. 
Hasil Pengujian hipotesis pertama dan kedua membuktikan information quality dapat memprediksi secara positif perceived trust. Konsumen akan mempertimbangkan faktor information quality dalam tingkat kepercayaan mereka. Faktor lain yang mempengaruhi kepercayaan konsumen adalah perceived web security dimana persepsi konsumen tentang keamanan website dapat mempengaruhi persepsi kepercayaan konsumen. Konsumen cenderung menilai suatu produk dari informasi yang ditemukannya kemudian diintegrasikan dengan informasi - informasi baik intrinsik maupun ekstrinsik yang kemudian di konversikan menjadi suatu penilaian subjektif konsumen yang mana hal tersebut dapat menjadi acuan dalam persepsi kepercayaan konsumen.

Pada hipotesis ketiga dan keempat yaitu convenience dan web interface quality tidak terbukti dapat memprediksi secara positif perceived ease of use konsumen Traveloka. Hal tersebut tidak sesuai dengan hipotesis yang dibangun peneliti yang menduga faktor kenyamanan dan tampilan antar muka dari website dapat membangun persepsi kemudahan dalam menggunakan Traveloka.

Pada hipotesis kelima yaitu brand image terbukti dapat memprediksi secara positif purchase intention konsumen Traveloka. Yang berarti konsumen akan mempertimbangkan faktor image dari suatu perusahaan ketika hendak memutuskan dalam melakukan suatu keputusan pembelian karena mencerminkan kualitas produk tersebut. Hal ini sesuai dengan penelitian dari Sutoyo \& Ariyanti (2017) \& Wani \& Farooq (2016).

Kemudian pada hipotesis keenam terbukti perceived trust dapat memprediksi secara positif terhadap purchase intention konsumen Traveloka. Hal tesebut dapat diartikan bahwa konsumen butuh percaya terhadap suatu merk atau perusahaan sebelum mereka memutuskan untuk bertransaksi atau membeli produk dari perusahaan atau merk tersebut. Hal ini sesuai dengan penelitian dari Sutoyo \& Ariyanti (2017) dan penelitian Afshardost \& Eshaghi (2013).

Terakhir pada hipotesis ketujuh terbukti bahwa perceived ease of use dapat memprediksi secara positif terhadap purchase intention konsumen Traveloka. Hal ini dapat diarikan bahwa konsumen tidak ingin melakukan extra effort untuk membeli atau bertransaksi untuk memperoleh sesuatu barang atau jasa yang konsumen inginkan. Hasil ini sesuai dengan penelitian dari Sutoyo \& Ariyanti (2017) dan Afshardost \& Eshaghi (2013).

\section{KESIMPULAN}

Berdasarkan hasil penelitian ini penulis dapat menyimpulkan: Information Quality \& Perceived Web Security memiliki pengaruh terhadap Perceived trust, Convenience \& Web Interface Quality tidak memiliki pengaruh terhadap Perceived Ease of Use. Brand Image memiliki mempengaruhi Purchase Intention hal ini sesuai dengan penelitian Sutoyo \& Ariyanti (2017) dan Wani \& Farooq (2016). Sementara Perceived Trust \& Perceived Ease of Use berpengaruh signifikan terhadap Purchase Intention hal ini sesuai dengan penelitian Sutoyo \& Ariyanti (2017) dan Afshardost \& Eshaghi (2013).

\section{Implikasi}

Temuan dalam penelitian ini memberikan implikasi manajerial yang bisa diterapkan oleh perusahaan. Peneliti menyarankan untuk perusahaan menaruh perhatian pada pentingnya information quality \& perceived web security untuk meningkatkan perceived trust konsumen, sementara perusahaan harus mencari tahu lebih lanjut faktor apa yang memiliki pengaruh terhadap perceived ease of use. karena dalam perceived trust dan perceived ease of use merupakan faktor yang mempengaruhi purchase intention konsumen perusahaan diharapkan meningkatkan kepercayaan konsumennya, dengan terus menambahkan fitur keamanan dan lainnya, mengeksplorasi dan mengembangkan user experience dan user interfacenya. Sementara terkait dengan faktor brand image penulis menyarankan agar perusahan dapat mendorong citra yang lebih kuat bagi konsumen yaitu dengan mengadakan campaigncampaign yang selaras dengan image brand perusahaan serta melakukan penyegaran brand 
dengan meluncurkan iklan, promosi, dll yang baru agar dapat menyegarkan dan memperkuat brand perusahaan.

\section{DAFTAR RUJUKAN/PUSTAKA}

Afshardost, M., Farahmandian, S., \& Saqiq Eshaghi, S. (2013). Linking trust, perceived website quality, privacy protection, gender and online purchase intentions. IOSR Journal of Business and Management, 13(4). DOI: 10.9790/487X-1346372

Australian Tourism Data Warehouse. (2013). Tutorial 39a On Line Travel Agents 101. Australia: Australian Tourism Data Warehouse.

Davis, F. (1989). Perceived usefulness, perceived ease of use, and user acceptance of information technology. MIS Quarterly, 13(3). DOI: 10.2307/249008

Edward C. S. Ku \& Yi Wen Fan. (2009). The decision making in selecting online travel agencies: an application of analytic hierarchy process. Journal of Travel \& Tourism Marketing, 26, 5-6. DOI: 10.1080/10548400903163020

Eid, M. I. (2011). Determinants of e-commerce customer satisfaction, trust, and loyalty in Saudi Arabia. Journal of Electronic Commerce Research, 12(1). DOI:10.2307/249008

Flavián, C., \& Guinalíu, M. (2006). Consumer trust, perceived security and privacy policy. Industrial management \& data Systems. Journal Emerald. Industrial Management \& Data Systems, 106(5). DOI: 10.1108/02635570610666403

Halim, H. (2019). Pengaruh user interface quality, information quality, perceived security, perceived privacy, belief, dan knowledge terhadap niat beli barang di website ecommerce di Indonesia. Jurnal Manajemen Bisnis dan Kewirausahaan, 3(2). DOI: 3.10.24912/jmbk.v3i2.4961.

Howard, J. A. (1994). Buyer Behavior in Marketing Strategy. USA: Prentice Hall.

Kim, S., \& Park, H. (2013). Effects of various characteristics of social commerce (s-commerce) on consumers' trust and trust performance. International Journal of Information Management, 33(2). DOI: 10.1016/j.ijinfomgt.2012.11.006

Kotler, P. \& Keller, K. (2012). Marketing Management $\left(14^{\text {th }}\right.$ ed.). New Jersey: Pearson Education, Inc, Prentice Hall.

Kotler, P., \& Amstrong, G. (2014), Principles of Marketing (12 ${ }^{\text {th }}$ ed.). Pearson Education, Inc, Prentice Hall.

Mahmuddhin, R. (2018, Mei 31). Pengguna Traveloka Naik Dua Kali Lipat Lebih. diakses dari https://akurat.co/id-236552-read-pengguna-traveloka-naik-dua-kali-lipat-lebih.

Mansour, K. B., Kooli, K., \& Utama, R. (2014). Online trust antecedents and their consequences on purchase intention: An integrative approach. Journal of Customer Behaviour, 13(1). DOI: 10.1362/147539214X14024779343677

Shneiderman, B. \& Plaisant, C. (2010). Designing the User Interface: Strategies for Effective Human-Computer Interaction. United States of America: Pearson Higher Education.

Sutoyo, R. A., \& Ariyanti, M. (2017). Factors influencing customer online purchase intention at Tokopedia.com. International Journal of Science and Research (IJSR), 6(7), DOI: $10.21275 /$ art20175246

Tejada, J. J., \& Punzalan, J. R. B. (2012). On the misuse of Slovin's formula. The Philippine Statistician, 61(1), 129-136.

Turban, E., King, D., Lee, J., Liang, T. P., \& Turban, D. C. (2010). Electronic Commerce. A Managerial Perspective (Global Edition, Vol. 6). New Jersey: Pearson.

Wani, T. A., Ali, S. W., \& Farooq, T. (2016). Determinants of online purchase intentions: a study of indian buyers. Amity Journal of Management Research AJMR Amity Journal of Management Research, 1(11), 94-109.

Wu, J. J., Chen, Y. H., \& Chung, Y. S. (2010). Trust factors influencing virtual community members: A study of transaction communities. Journal of Business Research, 63(9-10), DOI: 10.1016/j.jbusres.2009.03.022 